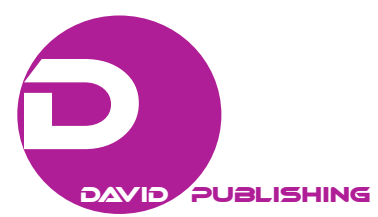

\title{
Women Empowerment in the Arab Region: Between the Anvil of Illiteracy and the Hammer of Passive Representative Bureaucracy
}

\author{
Salwa Thabet \\ Future University in Egypt, New Cairo, Egypt
}

\begin{abstract}
This paper emphasizes on enacting comprehensive mainstreaming institutional mechanisms to promote the role of women in socio-economic development in the Arab region. Sustainable development could never take place unless both the government and civil society are committed towards women empowerment and gender parity to achieve gender mainstreaming. However, cultural legacy, with its socioeconomic and political dimensions, is envisaged as the most challenging impediment. There are three critical areas of concern of substantive nature, which are high rates of women illiteracy, passive representative bureaucracy, as a result of underrepresentation at decision-making levels, as well as gender disparity. To investigate women empowerment challenges in the region, the study first presents the multifaceted hurdle of cultural legacy and identifies the relevant social, economic and political challenges from a multidisciplinary perspective. Thereafter, it looks at two inseparable issues facing women in the Arab region, illiteracy and underrepresentation at decision-making levels. The study, then, indicates the pressing need for policy changes to fill up the massive gender gap existing in the majority of Arab States, where not only a description of gender disparity profile of the Arab region is presented but also a comparative outlook vis-à-vis global trends is highlighted. Finally, the research identifies the indispensible roles of both the government and civil society to address key challenges in synchrony. It does not only call for placing women empowerment among the top priorities on the agenda of policy-makers in setting development plans, but also reiterates the significant role of civil society institutions in the areas of illiteracy eradication, civic education, and women rights advocacy. In this context, a framework of recommended policy actions is presented in an attempt to set effective women empowerment mechanisms to achieve gender mainstreaming and hence contribute to sustainable development.
\end{abstract}

Keywords: cultural legacy, gender mainstreaming, women empowerment, representative bureaucracy, illiteracy, gender parity

\section{Introduction}

Cultural legacy has always been a paradoxical challenge, among others, against upgrading women status in the Arab region. In fact, illiteracy, women underrepresentation and gender disparity are only symptoms of inherited epidemic social, economic and political issues which represent major barriers to achieving growth and sustainable socioeconomic development. High rate of illiteracy has been a core driver of lack of active

Salwa Thabet, Assistant Professor of Public Administration and Acting Vice Dean, Faculty of Economics and Political Science, Future University in Egypt. 
participation of women within their societies. In fact, discrimination against women has folded up passive representation of women especially at decision-making levels and this has been a core reason why policies have failed to address women shared interests and values.

Women constitute $49.1 \%$ of the total population of the Middle East and North Africa (MENA) region, while their workforce participation rate hits only $29.5 \%$ creating a huge gender gap in workforce reaching more than $40 \%$, as there are 36.7 females for every 100 males compared to a global rate of $66.9 \%{ }^{1}$ In addition, one of the core reasons behind the fact that youth in the Arab region, though they represent $33.3 \%$ of total population, which is a "demographic gift", compared to $14 \%$ globally globally ${ }^{2}$, represent only one third of the workforce is due to low participation of women. The consequence of this is that youth unemployment represents lost productivity to Arab economies with opportunity cost reaching $3 \%$ of GDP annually ${ }^{3}$. In addition, two third of the illiterate adults in the Arab region are women ${ }^{4}$.

Women "if properly recognized and employed, can make a difference in individuals' wellbeing and economic growth in urban and rural areas". Issues of gender parity and mainstreaming have become one of the top priorities on governments' agenda globally. Societies are coming to realize more and more every day the significant added value of women active participation in their communities contributing to socio-political and economic development. In light of this, the Arab region has to realize that in order to reposition itself among modern economies, it has to acknowledge the important role of women in the development of their societies and act on it. Hence, socioeconomic and political development strategies must reflect a new vision for more effective institutional mechanisms to address women empowerment, especially in policy process at both state and local levels with gender mainstreaming as a strategic goal.

In this study, both primary and secondary sources were used. Books, articles, and research papers were used to investigate the issue of gender inequality in two critical areas of concern, illiteracy and passive representation in policymaking in the Arab region in order to propose some effective institutional mainstreaming actions and mechanisms which would contribute to socioeconomic development. In addition, the study applied the system approach to analyze the different interrelated variables affecting women empowerment in the Arab region and identify the role of government and civil society as core determinants. In the research, women empowerment represent the independent variable and gender mainstreaming is the dependant variable.

\section{Women Empowerment and Cultural Legacy Challenges in the Arab Region}

Active participation of women in the Arab region has always been curtailed due to interrelated factors that have institutionalized a challenging cultural legacy as a stumbling block within societies. The study looks at key social, economic and political relevant issues which have to be recognized in order to identify realistic measures to empower potential female actors to become active agents of change within their societies and hence promote gender mainstreaming.

\footnotetext{
${ }^{1}$ Dubai Women Establishment, Arab Women Leadership Outlook 2009-2011, 1st ed., 2009, p. 40.

2 Jad Chaaban, Job Creation in the Arab Economies: Navigating Through Difficult Waters, Arab Human Development Report, UNDP, 2010, p. 13

3 Ibid., pp. 7, 22.

${ }^{4}$ UNESCO, Education for All—Regional Report for Arab States, Global Education for All Meeting, Paris, France, November 21-23, 2012, p. 11.

5 Malika Abdelali-Martini, Empowering Women in the Rural Labor Force with a Focus on Agricultural Employment in the Middle East and North Africa (MENA), UN Women, 2011, p. 2.
} 
Poverty has been an epidemic hurdle hindering women's active participation in the Arab region. Poverty is a multifaceted issue that have been one of the core factors that have formulated and institutionalized cultural legacy with inherited discrimination against women. In fact, we find that highest rates of illiteracy exist in marginalized poor rural areas ${ }^{6}$, where poverty is a major factor not only in illiteracy rates but in gender disparity as well. Poverty and lack of financial resources force families to give preference for males' education to females" "Poverty among the 22 members of the League of Arab States (LAS) is primarily a rural phenomenon". On average, $25 \%$ of the Arab region, 80 million, live below national poverty lines; among which $60-70 \%$ live in rural areas. ${ }^{8}$

Undoubtedly, illiteracy is key factor that curbs more political participation in the Arab region. One of the reasons that prevent them from fully receiving and enjoying these rights pertains to high rates of illiteracy which hamper awareness of rights and obligations ${ }^{9}$. Illiteracy has "deterred women from full participation" in workforce and political domain. We find that, in general, women with better education have more freedom of movement in the public sphere ${ }^{10}$. In addition, lack of women participation in the workforce in the MENA region, $29.5 \%$, does not only abstain socioeconomic development but also limit women access to independent sources of funds posing further barriers to active participation. Availability of financial resources is indispensible for standing for both parliamentary and local elections, for example, to support members of parliaments' constituents ${ }^{11}$. Furthermore, elections campaigns which have become increasingly costly have limited women candidates to only those who are well-off ${ }^{12}$.

Social Values Heritage is a dilemma in moving towards women empowerment in the Arab region. For decades, the tradition of early marriage and unfavourable social attitude towards females' education as well as low awareness about its importance especially in rural areas are considered core reasons for high rates of illiteracy among women ${ }^{13}$ as well as negligible participation of women in the public sphere. In spite of the fact that in most Arab States, constitutions and laws stipulate equality between men and women in rights and duties $^{14}$, yet inherited social values, similar to high rates of illiteracy especially in poor areas, further obstruct awareness of such rights and obligations ${ }^{15}$.

Patriarchal system and male social dominance stand to be a major obstacle to women's career path in the Arab region, in all domains, especially the political realm. Such system has resulted in the so called "traditional gender paradigm" which assumes that the most significant contribution of women in their societies is by being housewives and mothers ${ }^{16}$. Gender disparity relates to the fact that in almost all Arab States, parents are the "decision-makers" pertaining to the future of their daughters, where due to poverty, especially in rural provinces, "parents may feel that the anticipated returns on their investment in a daughter's education do not

\footnotetext{
${ }^{6}$ Malika Abdelali-Martini, Op. Cit., p. 2.

7 Shawn Magin, Illiteracy in the Arab Region: A Meta Study, GIALens, 2010, pp. 15-16. Retrieved from www.gial.edu/GIALens/ossues.htm.

${ }_{9}^{8}$ International Fund for Agricultural Development (IFAD), United Nations, IFAD and the League of Arab States, January 2009 , p. 1.

${ }^{9}$ Malika Abdelali-Martini, Op. Cit., p. 2.

${ }^{10}$ Institute for Democracy and Electoral Assistance, The Arab Quota Report: Selected Case Studies, Quota Report Series, 2004, p. 11.

11 Ibid., p. 15.

12 Dubai Women Establishment, Op. Cit., p. 36.

13 Hassan R. Hammoud, Illiteracy in the Arab World, UNESCO, 2005, p. 5.

14 United Nations Development Program, Arab Human Development Report: Towards the Rise of Women in the Arab World, 2005, p. 18.

15 Malika Abdelali-Martini, Op. Cit., p. 2.

${ }^{16}$ Institute for Democracy and Electoral Assistance, Op. Cit., pp. 11-12.
} 
justify the expected cost, and they will prefer income-generating activities or marriage". ${ }^{17}$ In addition, in many cases, we find that a woman follows her husband sectarian affiliation and vote for the candidate whom the family supports rather than pertaining to her own preferences.

Male dominance culture has further been institutionalized in political parties which are generally described to be internally undemocratic ${ }^{18}$, even liberal and leftist parties. Political parties focus only on major policy issues, such as poverty and unemployment but overlook women issues. In addition, they marginalize women's role in the political party. In fact, women usually occupy "social or clerical" tasks as positions are "gender-based". In addition, the political culture is widely characterized by scepticism about women's political abilities. Male-dominated political realm has not only demotivated women to join political parties ${ }^{19}$, but, in fact, in many cases we find women to be highly reluctant to vote for female candidates ${ }^{20}$.

Furthermore, traditions and social values have imposed limitations on women freedom of movement which have further hampered women active participation in the public sphere. Moreover, patriarchal societies have given rise to lack of feminist ideology that would boost progress toward women advancement. This is vividly observed in the weak women's movements ${ }^{21}$.

Political Instability in many Arab States has been another important factor in depriving 1000s of women from formal education especially in countries where there is vast size of dispersed lands with low levels of population density, such as Yemen, Egypt, Morocco, and Sudan ${ }^{22}$. This has forced many families not to send their girls to school in distant location from home especially at time of political unrest ${ }^{23}$.

Democratization process in some Arab States, such as Tunisia and Egypt, might contribute to create an environment where women movements and civil society organizations could strive and "lobby for their rights and participation in society contrary to closed political systems which put constraints, especially to youth and women" ${ }^{24}$. However, nowadays, with political instability and lack of security in many other Arab States, such as Iraq, Libya, Syria, etc. gender mainstreaming has been further hampered and restrained, especially as a result of religious extremists groups such as the Islamic State of Iraq and Syria (ISIS), imposes paradoxical restrictions on females' education and political participation.

Lack of Government Support to promote women active participation as decision-makers in almost all domains has further sustained the long existing culture legacy. In the Arab region, unfortunately, some policymakers still cannot perceive the impact of gender equality, schooling in rural areas and capacity building efforts on the overall poverty reduction and improvement of livelihoods ${ }^{25}$. Governments address women's issues in isolation from national policies and economic reforms programs. Sustainable development through socio-economic development would never take place unless there is a unified commitment by both the government and civil society towards gender parity and women's empowerment ${ }^{26}$ and unless gender parity issues are squared with development plans.

17 Shawn Magin, Op. Cit., pp. 15-16.

18 Institute for Democracy and Electoral Assistance, Op. Cit., p. 7.

19 Ibid., pp. 14-15.

20 Dubai Women Establishment, Op. Cit., p. 35.

21 Institute for Democracy and Electoral Assistance, Op. Cit., pp. 11-12.

${ }^{22}$ UNESCO Regional Bureau for Education in the Arab States, Op. Cit., p. 41.

23 Shawn Magin, Op. Cit., p. 17.

24 Dubai Women Establishment, Op. Cit., p. 35.

25 Malika Abdelali-Martini, Op. Cit., p. 12.

26 Ibid., pp. 1-2. 
Lack of political support and commitment to eradicate women's illiteracy represents a paradoxical challenging hurdle ${ }^{27}$. In addition, although political rights are considered as a main determinant of the extent to which the political environment is conducive to promoting women political participation, yet it is not the only variable. Despite of the fact that women have been granted their political rights by constitutions which stipulate the principle of gender equality in political participation, in electoral process and standing for public office, in many countries (see Figure 1) ${ }^{28}$, still Arab States hit lowest global records in women political participation. Lack of participation is not only due to social factors and illiteracy but also due to the persisting lack of political support. This could explain the negligible number of head counts in political leadership positions which are perceived to be more as symbolic rather than active actors. ${ }^{29}$ As a result, women have not fully received their political entitlements. ${ }^{30}$

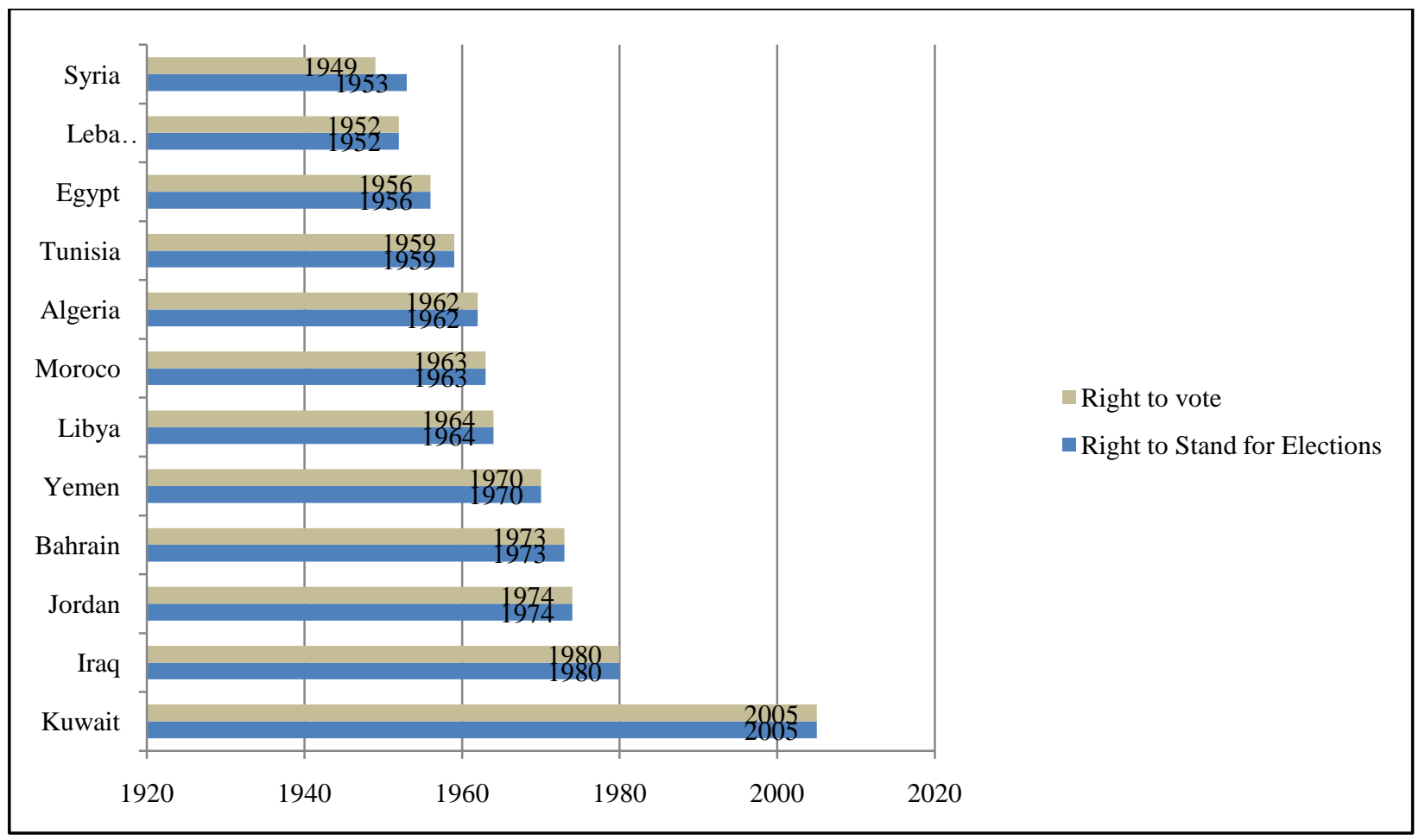

Figure 1. Arab women rights to: Vote \& Stand for elections. Source: Inter-Parliamentary Unit, 2009.

\section{Illiteracy, Passive Representative Bureaucracy and Gender Disparity}

Cultural legacy in the Arab region has resulted in sever interrelated gender issues, aforementioned, standing as the major barrier towards gender mainstreaming in the Arab region. This section of the research highlights the steepness of the chronic outcomes of cultural heritage, focusing on women illiteracy, passive bureaucratic representation and gender disparity. It highlights existing profile in the Arab region and presents a comparative outlook to global trends.

\footnotetext{
27 Hassan R. Hammoud, Op.Cit., p. 13.

28 Inter-Parliamentary Unit, Women Suffrage: A World Chronology of the Recognition of Women's Rights to Vote and to Stand for Election, 2009. Retrieved from http://www.ipu.org/wmn-e/suffrage.htm.

29 Dubai Women Establishment, Op. Cit., pp. 37, 61.

${ }^{30}$ Institute for Democracy and Electoral Assistance, Op. Cit., p. 13.
} 


\section{Women Illiteracy Epidemics in the Arab Region}

The Arab region needs 45 years to abolish illiteracy as illiteracy annual decrease is $0.9 \%$ on average assuming same pace of illiteracy eradication as well as number of illiterates ${ }^{31}$. In spite of the decline of illiteracy rate from 1970 to 2008 from $74 \%$ to $40 \%$, yet number of illiterates increased from 50 million to 70 million respectively ${ }^{32}(34 \% / 38$ years $=0.9 \%)$. Chronic social, economic and political issues, explained above, have widened the literacy gap between males and females in the Arab region as well as created massive challenges especially in rural areas where almost $44 \%$ of the population of Arab States live ${ }^{33}$.

Unfortunately, adult literacy in the Arab region is among the lowest global wide, which indicates a menacing threat to the region's ability to realize sustainable socio-economic development. According to 2008 indicators, the majority of the world illiterate adults exist in less-developed regions, namely, South and West Asia hitting 41\%, Sub-Saharan Africa 40\%, the Arab States 37\%, Latin America and the Caribbean 10\% and 9\% in East Asia and the Pacific (Sage Knowledge, 2013, pp. 475-476). Most importantly, as aforementioned, two third of the illiterate adult population in the Arab States are women (see Figure 2) ${ }^{34}$.

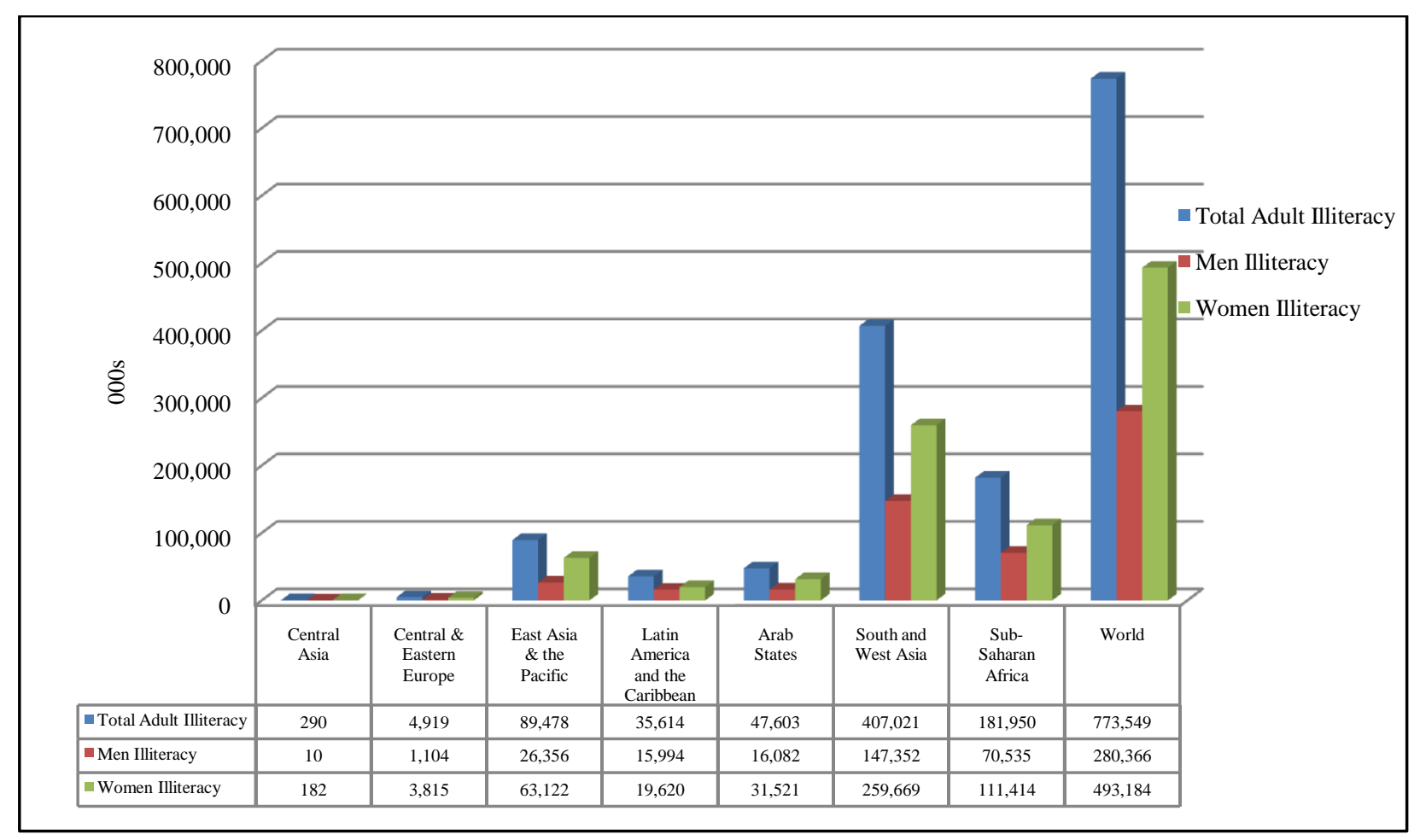

Figure 2. Global Illiterate Adult Population \& Gender Disparity 2011, Source: UNESCO Institute for Statistics, June 2013.

Illiteracy persists to be a major challenge facing Arab States to reposition themselves among modern economies. Looking at success stories of strong economies like Japan, Brazil, and Malaysia, with literacy rates hitting 99\% (males: 99\%, females: 99\%), 90.4\% (males: 90.1\%, females: $90.7 \%$ ) and $93.1 \%$ (males: $95.4 \%$,

\footnotetext{
31 Salwa Thabet, Arab Literacy Project: Revival of the League of Arab States, 3rd Global Conference on Public Policy and Administration in the Middle East, Lebanon, December 5-6, 2014, p. 10.

32 Shawn Magin, Op. Cit., pp. 1-2.

33 United Nations, Arab States: A World of Cities, 2013, p. 1. Retrieved from http://www.un.org/ga/Istanbul+5/13.pdf.

${ }^{34}$ UNESCO Institute for Statistics (UIS), Adult and Youth Literacy National, Regional and Global Trends, 1985-2015, June 2013, p. 10. Retrieved from http://www.uis.unesco.org/Education/Documents/literacy-statistics-trends-1985-2015.pdf.
} 
females: 90.7\%) respectively; and GDP per capita (PPP) are US\$ 37,100, US\$ 12,100, and US\$ 17,500; while in some Arab States such as Egypt, Morocco, and Yemen, literacy rates hit 73.9\% (males: 81.7\%, females: 65.8\%), $67.1 \%$ (males: $76.1 \%$, females: $57.6 \%$ ) and $65.3 \%$ (males: $82.1 \%$, females: $48.5 \%$ ) and GDP per capita (PPP) are US\$ 6,600, US\$ 5,500, and US\$2,500 respectively ${ }^{35}$, we find that there is a positive correlation between literacy, education gender parity and economic growth. We could assert that both literacy and gender parity are indispensible for achieving sustainable development and hence have become top priority policy issues for the Arab region.

\section{Passive Women Representative Bureaucracy}

Representative bureaucracy approach claims that when public agencies workforce reflect demographic characteristics of population is most likely to act in line the citizenry policy preferences (Robert \& Janet, 2006, p. 138). This is based on the principle that when bureaucracies at all levels: policy-making, middle and street-level, represent the diversity in the society, presumably they will be more responsive to their interests and needs in policymaking on one hand and will give legitimacy to these bureaucracies on the other. Bureaucracies according to scholars like Waldo, Allison, Wilson, and Seidman are "political policymaking institutions". This theory emerged in consistency with basic democratic values of "majority rule, minority rights and equal representation". However, unless this equitable representation is reflected into decision and actions pertaining to the general public will, it is considered as passive rather than active representation (Frederickso \& Kevin, 2003, pp. 61-63). Hence it is not only a matter of number count of women represented in the bureaucratic apparatus but rather their active participation, especially, at decision-making levels in response to the general citizenry values and interests. This research borrows representative bureaucracy approach to study variables affecting gender mainstreaming ${ }^{36}$ in the Arab region and propose effective actions and mechanisms of women empowerment to promote gender parity.

Gender mainstreaming could never be realized unless there are strategies to ensure increasing women's representation in politics and public policy process. By looking at the parliamentary level, there is a wide range of discrepancies existing among Arab States. According to 2014 indicators, remarkably both Algeria and Tunisia, reaching respectively $31.6 \%$ and $31.3 \%$ women parliamentary representation and ranked 28 and 31 globally, were both able to hit the critical mass (30\%). Other Arab States are also placed on the top of the list of Arab States in terms of women parliamentary representation, such as South Sudan and Iraq corresponding to $26.5 \%$ and $25.3 \%$, then moving down to hit its lowest rates in countries like Kuwait, Oman, Yemen, and Qatar with $1.5 \%, 1.2 \%, 0.3 \%$, and $0.0 \%$ respectively (see Table 1$)^{37}$.

Looking at global trends, the Women in Parliament Report 2013 indicated that women's representation in the parliament increased from $11.3 \%$ to $21.8 \%$ in 1995 and 2013 respectively, representing an increase of

\footnotetext{
${ }^{35}$ Central Intelligence Agency, The World Factbook. Retrieved from https://www.cia.gov/idex.htm.

36 "Mainstreaming a gender perspective is the process of assessing the implications for women and men of any planned action, including legislation, policies or programmes, in all areas and at all levels. It is a strategy of making women's as well as men's concerns and experiences an integral dimension of the design, implementation, monitoring and evaluation of policies and programmes in all political, economic and societal spheres so that women and men benefit equally and inequality is not perpetuated. The ultimate goal is to achieve gender equality" (United Nations, Division for the Advancement of Women (DAW), Economic Commission for Latin America and the Caribbean (ECLAC), National Machineries for gender Equality, Expert Group Meeting Report, Santiago, Chile, 31 August-4 September, $1998 . \quad$ Retrieved from http://www.un.org/womenwatch/daw/news/natlmach.htm.

37 Inter-Parliamentary Union, Women in National Parliaments, December 2014. Retrieved from http://www.ipu.org/wmn-e/classif.htm.
} 
$10.5 \%$ in 16 years posing a menacing threat to achieve gender parity through gender mainstreaming (Bishu \& Jean-Claude, 2014, pp. 231-232). This indicates that one of each 5 parliamentarians is a woman. In addition, by January 2014, only 9 women served as Head of State while 15 as Head of Government. Global indicators assert that women account for less than $10 \%$ of the parliaments members in either single or lower houses in 38 states $^{38}$. Despite of the overall low global participation of women in political and policy making institutions, still there is a wide range of variations among the different regions. Nordic countries hit the highest women representation rates scoring $42.1 \%$ while the Arab States score only $16 \%$ placing it at the bottom of the list (see Figure 3$)^{39}$.

Table 1

Arab States Global Ranking of Women Representation in National Parliaments-2014

\begin{tabular}{|c|c|c|c|c|c|c|c|c|c|}
\hline \multicolumn{10}{|c|}{ World Classification } \\
\hline \multirow{2}{*}{ Rank } & \multirow{2}{*}{ Country } & \multicolumn{4}{|c|}{ Lower or single House } & \multicolumn{4}{|c|}{ Upper House or Senate } \\
\hline & & Elections & Seats $^{*}$ & Women & $\% \mathrm{~W}$ & Elections & Seats $^{*}$ & Women & $\% \mathrm{~W}$ \\
\hline 28 & Algeria & 52012 & 462 & 146 & $31.6 \%$ & 122012 & 144 & 10 & $6.9 \%$ \\
\hline 31 & Tunisia & 102014 & 217 & 68 & $31.3 \%$ & --- & --- & --- & --- \\
\hline 50 & Iraq & 42014 & 328 & 83 & $25.3 \%$ & --- & --- & --- & --- \\
\hline 51 & Mauritania & 112013 & 147 & 37 & $25.2 \%$ & 112009 & 56 & 8 & $14.3 \%$ \\
\hline 54 & Sudan & 42010 & 354 & 86 & $24.3 \%$ & 52010 & 29 & 5 & $17.2 \%$ \\
\hline 72 & Saudi Arabia & 12013 & 151 & 30 & $19.9 \%$ & --- & --- & --- & --- \\
\hline 85 & United Arab Emirates & 92011 & 40 & 7 & $17.5 \%$ & --- & --- & --- & --- \\
\hline 87 & Morocco & 112011 & 395 & 67 & $17.0 \%$ & 102009 & 270 & 6 & $2.2 \%$ \\
\hline 92 & Libya & 62014 & 188 & 30 & $16.0 \%$ & --- & --- & --- & --- \\
\hline 101 & Somalia & 82012 & 275 & 38 & $13.8 \%$ & --- & --- & --- & --- \\
\hline 109 & Djibouti & 22013 & 55 & 7 & $12.7 \%$ & --- & --- & --- & --- \\
\hline 112 & Jordan & 12013 & 150 & 18 & $12.0 \%$ & 102013 & 75 & 9 & $12.0 \%$ \\
\hline 112 & Syrian Arab Republic & 52012 & 250 & 30 & $12.0 \%$ & --- & --- & --- & --- \\
\hline 131 & Bahrain & 112014 & 40 & 3 & $7.5 \%$ & 112010 & 40 & 11 & $27.5 \%$ \\
\hline 141 & Lebanon & 62009 & 128 & 4 & $3.1 \%$ & --- & --- & --- & --- \\
\hline 142 & Comoros & 122009 & 33 & 1 & $3.0 \%$ & --- & --- & --- & --- \\
\hline 145 & Kuwait & 72013 & 65 & 1 & $1.5 \%$ & --- & --- & --- & --- \\
\hline 146 & Oman & 102011 & 84 & 1 & $1.2 \%$ & 102011 & 83 & 15 & $18.1 \%$ \\
\hline 147 & Yemen & 42003 & 301 & 1 & $0.3 \%$ & 42001 & 111 & 2 & $1.8 \%$ \\
\hline 148 & Qatar & 72013 & 35 & 0 & $0.0 \%$ & --- & --- & --- & --- \\
\hline
\end{tabular}

Notes. Source: Inter-Parliamentary Union, December 2014. N.B.: Egypt is not included in the table as there was no parliament in 2014. Women's parliamentary representation in Egypt hit $13.2 \%$ in $2012^{40}$. In addition, available data on women's representation in the Palestinian Legislative Council indicates $13 \%$ female members in $2006^{41}$.

38 UN Women, Facts and Figures: Leadership and Political Participation, 2014, p. 1. Retrieved from http://www.unwomen.org/en/what-we-do/leadership-and-political-participation/facts-and-figures.

39 Sebawit G Bishu and Jean-Claude Carcia-Zamor, Op. Cit., pp. 231-232.

40 Inter-Parliamentary Union, Women in Parliament in 2012: The Year in Perspective, 2013, p. 5. Retrieved from http://www.ipu.org/pdf/publications/WIP2012e.pdf.

${ }^{41}$ International Institute for Democracy and Electoral Assistance (International IDEA), Gender Quota in Special Areas-Palestine Territory, Occupied, 2006, p. 1. Retrieved from http://www.idea.int/gender/quotas_special_areas.cfm?country=183. 


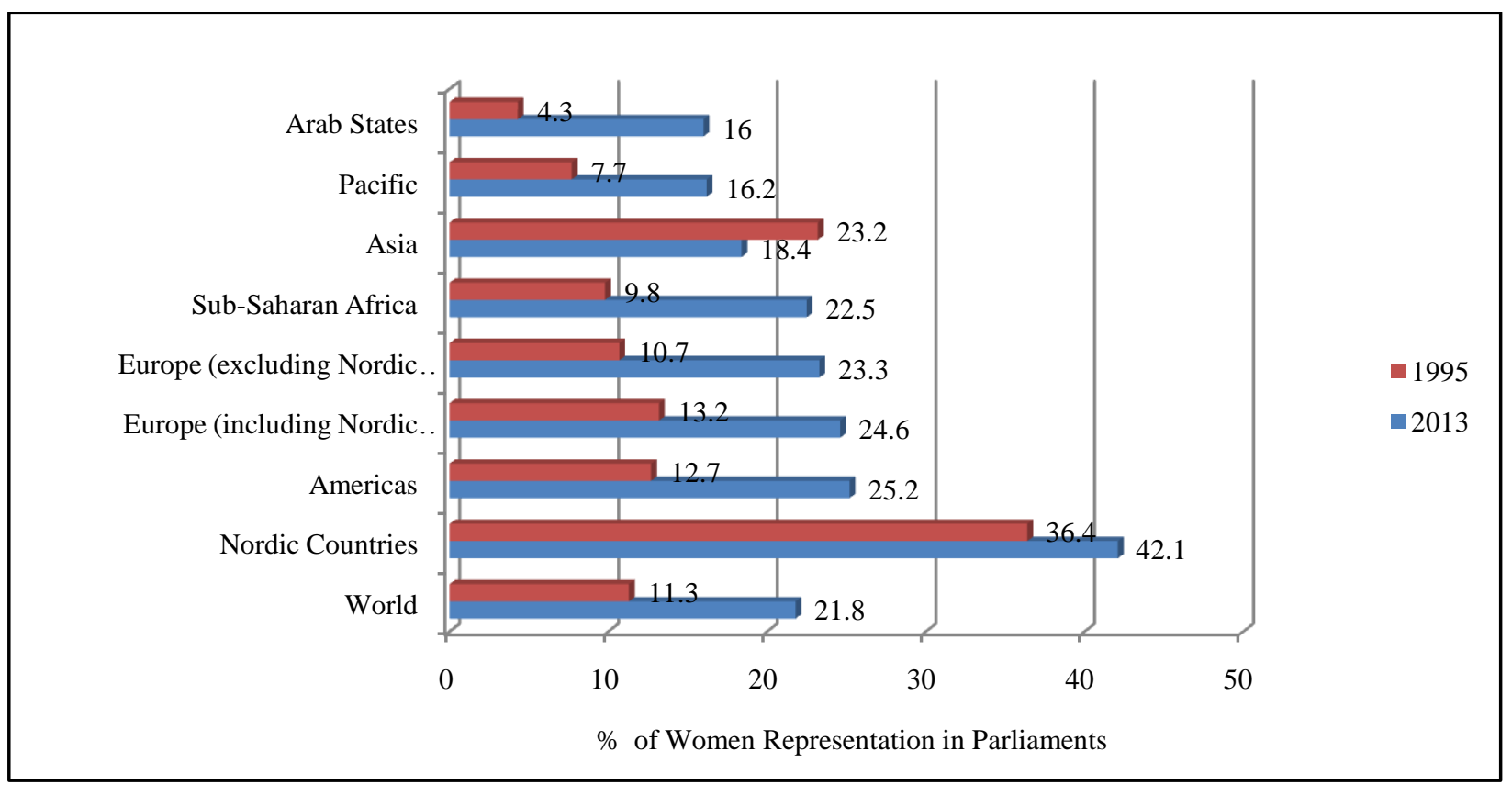

Figure 3. Women in the Parliament-World \& Regional Averages. Source: Women in Parliament Report in 2013.

Looking at domains other than the parliamentary representation, women ministers in the Arab region, according to 2014 indicators, hits the lowest rate globally, occupying only $8.3 \%$ where the majority fall in the social sectors. Viewing global trends, we find that the Americas hit the highest percentage of women ministers at $22.9 \%$, followed by Africa with $20.4 \%$, Europe $18.2 \%$, despite of the fact that the Nordic countries reached 48.9\%, Pacific $12.4 \%$, Asia $8.7 \%$ and finally the Arab region with the lowest rate of $8.3 \%$. However, eight countries that have no women ministers, of which two are from the Arab region-Lebanon, Saudi Arabia; the other six are: in Asia-Pakistan and Brunei Darussalam, in Europe - San Marino and Bosnia and Herzegovina, and in the Pacific - the Solomon Islands and Vanuatu. ${ }^{42}$

Moreover, at the local government level where experts believe that "women politicians can be active advocates of women's issues among their colleagues in the local government and vital for mainstreaming gender perspectives in policies" ${ }^{43}$. In Egypt as an example of Arab States, women account for only 5\% in local councils compared to 30\% in the United States, $40 \%$ in India and 50\% in Sweden according to 2005 indicators. Global data available in 2005 indicates that, based on 60 countries distributed among all regions, women were $9 \%$ only of all mayors and about $21 \%$ of councilors (Saleh El-Sheikh, 2008, p. 6).

\section{Gender Disparity in the Arab Region}

Within the context of democratic governance as well as institutional development in Arab States, both issues of gender inequality and passive women representation in decision-making levels stand as chronic challenges. We refer here to the global gender gap index (GGGI) — which measures the gap between men and women against four categories: Economic Participation and Opportunity; Educational Attainment; Health and Survival; and Political Empowerment, the later considers 3 major factors/ratios: females to males in

\footnotetext{
42 Inter-Parliamentary Union, Progress for Women in Politics, but Glass Ceiling Remains Firm, Press Release, Geneva, March 11, 2014. Retrieved from http://www.ipu.org/press-e/pressrelease201403111.htm.

43 International Knowledge Network of Women in Politics, Women in Local Governments. Retrieved from http://iknowpolitics.org/en/discuss/circles/women-local-governments.
} 
parliaments; females to males at ministerial level; number of years of a female head of state over male value ${ }^{44}$. Middle East, of which most Arab States are part of, has closed only 7\% of its gender gab concerning political empowerment ${ }^{45}$. The Arab States are among the lowest rankings of the 142 countries assessed (see Figure 4). Overall global ranking indicates Yemen to be ranked the lowest globally with gender gap index of 0.51 , while Kuwait, globally ranked 113, is identified to be the best among Arab States with an GGGI hitting 0.65 (see Table 2$)^{46}$.

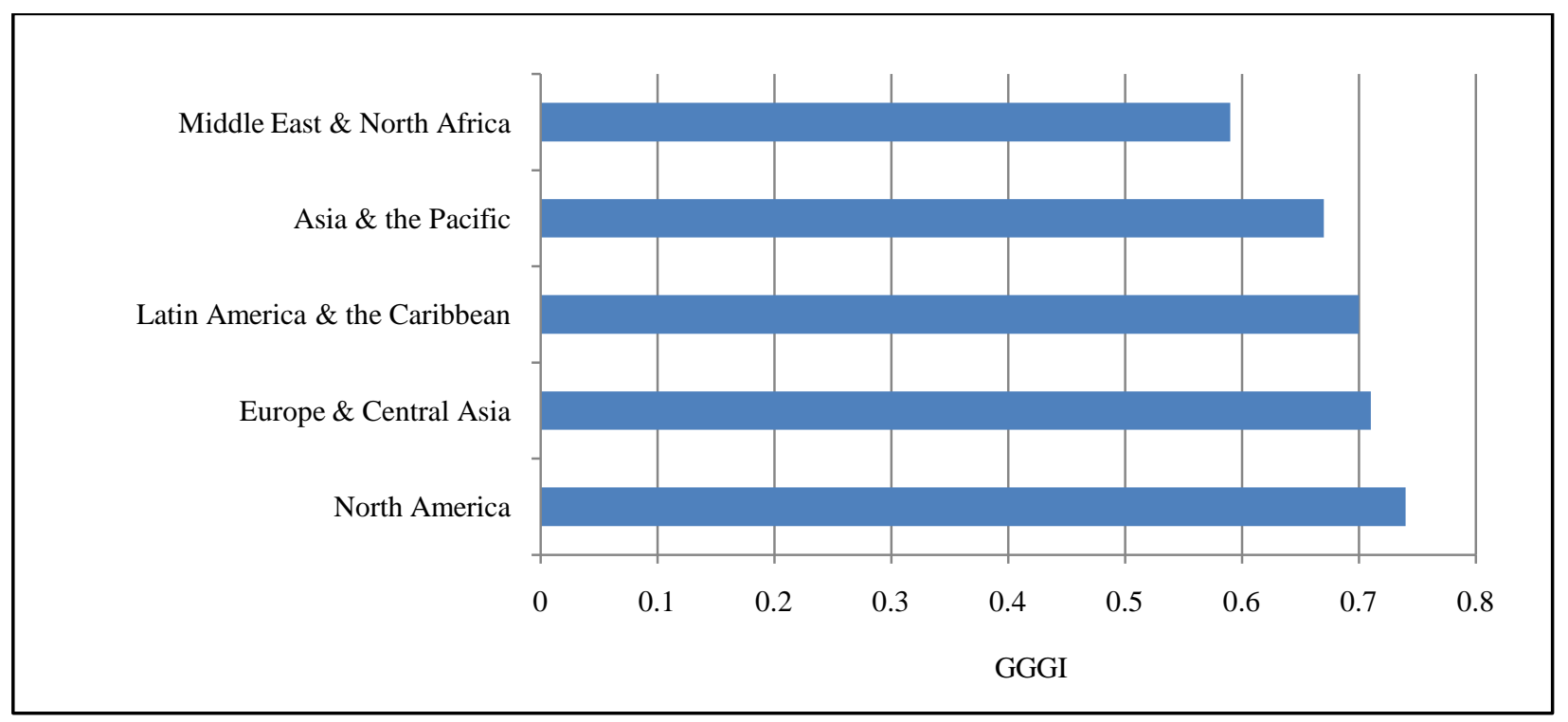

Figure 4. Global Gender Gab Index Score-GGGI (0.00-1.00). Source: The Global Gender Gap Report 2013.

Table 1

Global Ranking \& GGGI of 15 Arab States

\begin{tabular}{llll}
\hline No & Country & GGGI & Rank \\
\hline 1 & Kuwait & 0.6457 & 113 \\
2 & United Arab Emirates & 0.6436 & 115 \\
3 & Qatar & 0.6403 & 116 \\
4 & Tunisia & 0.6272 & 123 \\
5 & Bahrain & 0.6261 & 124 \\
6 & Algeria & 0.6182 & 126 \\
7 & Oman & 0.6091 & 128 \\
8 & Egypt & 0.6064 & 129 \\
9 & Saudi Arabia & 0.6059 & 130 \\
10 & Mauritania & 0.6029 & 131 \\
11 & Morocco & 0.5988 & 133 \\
12 & Jordan & 0.5968 & 134 \\
13 & Lebanon & 0.5923 & 135 \\
14 & Syria & 0.5775 & 139 \\
\hline
\end{tabular}

44 World Economic Forum, The Global Gender Gap Report 2013, p. 5. Retrieved from http://www.weforum.org/docs/GGGR14/GGGR_Complete Report_2014.pdf.

45 Ibid., p. 16.

46 Ibid., p. 9. 


\section{Role of Government and Civil Society to Set-off Women Empowerment: Highlights on the Egyptian Case}

Since almost 50\% of the Arab labour force pool is women, hence women's active participation in their societies economically, socially and politically contributes to how these communities are built and developed. Women empowerment and gender equality have become envisaged as prerequisites for achieving sustainable development. With the Arab region being far from achieving gender parity and mainstreaming, this calls for a pressing need for dramatic policy changes and collaborative actions among government, civil society, and media.

One of the key international declarations addressing gender mainstreaming is Beijing Declaration and Platform for Action which aims at taking measures to "ensure women's equal access to and full participation in power structures and decision-making" ${ }^{47}$. Legal framework which only focus on the principle of removing restrictions on women participation in the political realm and stipulates gender parity in political rights and obligations is integral to provide equal gender opportunities for career and political participation advancement, yet proved to be insufficient to institutionalize gender parity and promote gender mainstreaming due to cultural limitations. Hence, the legal framework should transcends the mere removal of restrictions on women participation, and rather take more effective measures to overcome cultural limitations. In addition, a legal framework with absence of a real political will and support as well as effective collaboration between civil society advocacy organizations and policymakers to empower women and promote gender mainstreaming, could only trigger a more active role of women in the public sphere but highly risks its sustainability. The environment in which political participation takes place needs to dramatically change to create a platform more conducive to women active participation and encouraging for women to advance their status and become leadership role models. The study attempts to present a framework of proposed guidelines and measures which, in synchrony, could contribute to developing more gender-neutral based societies moving towards gender mainstreaming. Figure 5 illustrates variables and mechanisms which determine cultural legacy. It also identify the important role of both the government and civil society in women empowerment to face challenges of illiteracy, lack of women political participation, and gender disparity towards achieving gender mainstreaming which significantly contributes to sustainable development.

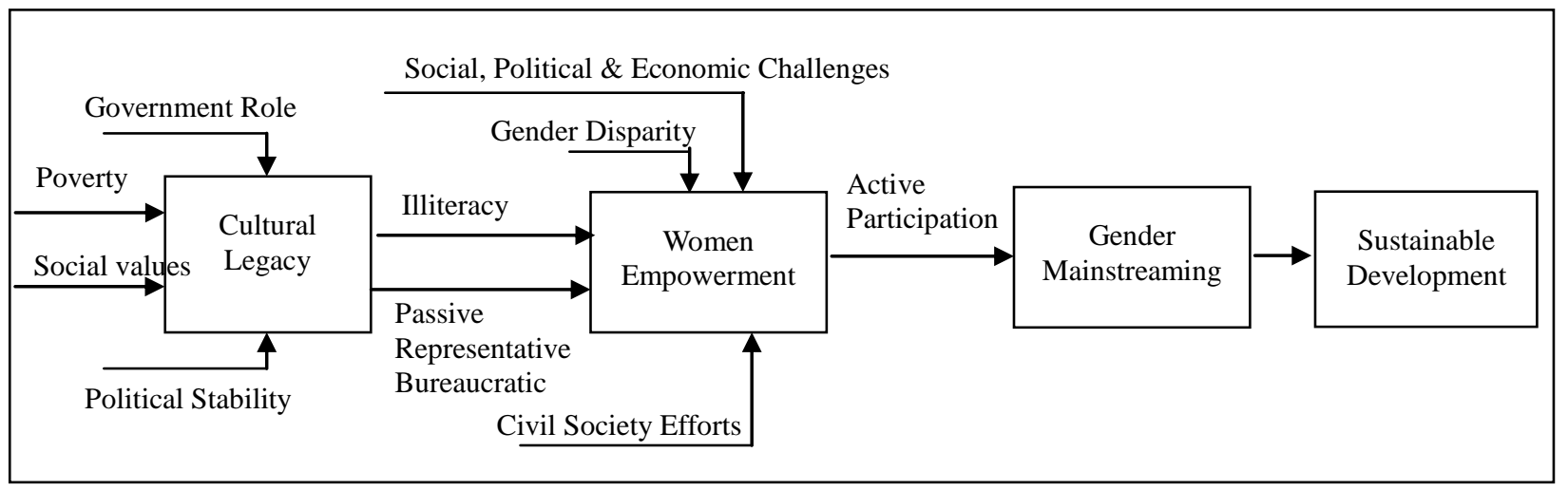

Figure 5. Women empowerment mechanism.

\footnotetext{
47 Minnesota Advocates for Human Rights, Summary of the Beijing Declaration and Platform for Action, January 1996, p. 27. Retrieved from http://www.theadvocatesforhumanrights.org/uploads/declaration.pdf.
} 


\section{Role of the Government}

\section{Legal Framework}

Though a quota system might reflect lack of neutrality and affirm the value of a gender-based society, and though head counts do not necessarily ensure active participation with shared value of gender equality that results in policy influence ${ }^{48}$, yet in an environment where women play almost negligible political role and face discrimination to reach out for leadership positions, increasing head counts could be an important step toward change. A global benchmark for women's parliamentary representation is $30 \%$, the so-called critical mass. Worldwide, 39, single or lower, houses surpassed 30\% women each, 11 in Africa and 8 in Latin America. 32 out of these 39 houses implemented different forms of quota systems to promote for women political participation ${ }^{49}$. Effective legal measures have become imperative to increase women participation in policy-making even if it doesn't directly solve cultural core issues.

In the case of Egypt, article 11 of the constitution 2013 stipulates that the state is committed to take the necessary measures to ensure appropriate representation of women in the parliament. The State shall also guarantee women's right in holding public and senior administrative positions in the State and in judicial bodies and authorities without discrimination. In addition, article 53, stipulates that all citizens are equal before the law having equal rights, freedoms and duties without discrimination based on religion, belief, sex, origin, race, colour, language, disability, social class, political or geographic affiliation or any other reason ${ }^{50}$. Such articles affirm a legal framework for gender equality. However, since such measures are not enough to ensure a reasonable increase in women political participation, other legal measures were enacted. At the state level, the electoral law will ensure, at least, 70 seats for women (12.3\% of a total 567 seats), of which 56 out of the 120 parliamentary seats assigned to political parties' lists as at least 3 women candidates are to be on each list, as well as 14 will be appointed by the president — which account for $50 \%$ of the $5 \%$ to be appointed by the President ${ }^{51}$.

Local governments are the real incubators for creating active female political leaders. Elected leaders as well as appointed administrators in local councils develop, especially with an increasing political commitment to decentralization, professionalism through hands-on knowledge and skills relevant to policymaking and policy implementation in their communities. Hence, there are high chances that leaders on a municipal level develop to become potential agents of change on a state level in the future.

Women's active participation at the local level has been globally acknowledged to have high potentials to contribute to socioeconomic development of their local communities and societies at large. There are examples of how, at the local level, women's active participation has been highly recognized to enact change. India, a vivid example, where indicators asserted that local councils led by women implemented a number of drinking water projects $62 \%$ higher than those implemented by men-led councils. In addition, in Norway, there was a positive correlation drawn between representation of women in municipal councils and childcare coverage ${ }^{52}$.

In Egypt, the amended constitution 2013, Article 180, stipulates that $25 \%$ of the seats of local council are

\footnotetext{
${ }^{48}$ Sebawit G Bishu and Jean-Claude Carcia-Zamor, Op. Cit., p. 233.

${ }^{49}$ UN Women, Op. Cit., p. 2.

50 The Egyptian Constitution 2013, pp. 8, 18.

51 Monica Micheal Hanna, Arab-West Report, Women in Parliament: Gender Justice for Egyptian Women? December $18,2014$. Retrieved from http://www.arabwestreport.info/year-2014/week-50/03-women-parliament-gender-justice-egyptian-women.

${ }^{52}$ UN Women, Op. Cit., pp. 1-2.
} 
allocated to females ${ }^{53}$. Such a policy would ensure high women's leadership representation at the local level, but most importantly would create a platform for women role models attracting women who aspire opportunities for success in both rural and urban communities across all regions in Egypt. The impact of such measures of empowerment, especially in rural areas, could affect other domains, such as education, as providing opportunities for advancing women status could be a major drive to eradicate women illiteracy on one hand, and could also provide prospects to formulate and enact policies which address gender issues on the other. The constitution, in this context, could contribute to changing the environment and hence could contribute to sustainability of an increasing role of women as active agents of change rather than symbolic representation.

\section{Political Will}

In spite of the fact that setting a legal framework that empowers women and increase its representation in the political realm reflects the presence of a political will to move the society towards gender mainstreaming, yet to ensure sustainability of women's active participation, strong political will and support for promoting the role of women must be further institutionalized within the society. The following present critical actions in some key areas where government support and gender mainstreaming actions have become indispensible:

Integrate gender parity issues within national socioeconomic plans rather than addressing it in isolation of strategic plans. Industrialization development plans should emphasize the significant added value of women's active participation which could contribute to boosting the industrialization process. For example, grants for micro and small projects should put women as one of the main target groups especially in marginalized rural areas where high poverty rates persist. Such projects must also entail capacity building programs, such as marketing programs to provide female entrepreneurs with required skills and hence increase chances of success. In addition, illiteracy eradication projects should as well target women especially in poor areas, yet should be based on hands-on learning methods in accordance to areas of specialization, i.e., adopting the functional approach, to ensure positive impact of such literacy projects on learners' contribution to socioeconomic development of their communities. Development plans, as one of its key strategic goals, should focus on empowering women in all the different domains.

Provide equal employment opportunity for women at top levels in the different fields of interest, including judicial and executive branches.

Appoint women in executive positions at the different local levels, including governorates, regions, and villages. Such executive positions range from governors, district officers, and mayors. Such a trend would introduce female leaders as role models in their communities and hence motivate others with leadership aspirations to work hard and develop their capabilities to reach out for leadership positions. With such vision, dramatic cultural changes would take place on the long run with faster steps toward gender mainstreaming.

Ensure fairness in pay, compensation and promotion within public organizations by implementing a merit system where objective performance criteria are the main determinants of pay, benefits and promotion decisions. In fact, many women face discrimination at workplace and perceive the challenge of recognition as a main obstacle, and consequently they have to do almost double the work of their male incumbents to get promoted $^{54}$.

\footnotetext{
53 The Egyptian Constitution, Op. Cit., pp. 45-46.

54 Dubai Women Establishment, Op. Cit., p. 26.
} 
Revise curriculum of schools to ensure integrating values of gender equality on one hand while highlighting outstanding Arab women figures and their contributions in the different economic, social, political and cultural domains.

Implement government reengineering to move toward achieving lower levels of corruption. Democratic and transparent politics is positively correlated to lower levels of corruption which creates an environment conducive to more active women political participation ${ }^{55}$.

\section{Role of Civil Society}

Financial support. Success in elections, especially parliamentary, is highly contingent upon availability of financial resources which persist to be one of the major barriers restraining women's political participation. In Egypt, for example, though political parties in collaboration with National Council for Women $(\mathrm{NCW})^{56}$ promised to pay the insurance fees for women parliamentary candidates who are financially unable to pay (LE 3,000 for individual candidates and LE 6,000 for those running on the list) (Leila, 2015), yet still financial resources needed for electoral campaigns stand as an unsolved riddle for women candidates to achieve effective public exposure to be able to introduce themselves and their programs to constituents. The government to allocate on a temporary basis, as an example, a budget-line to support women's political participation especially for electoral campaigns purposes, in case there are available resources $^{57}$, is highly questionable especially for countries in transition facing political and economic challenges. In light of this, the significant role of civil society advocacy organizations stems out, where they could launch donation campaigns initiatives for the purpose of supporting electoral women candidates ${ }^{58}$ for parliaments or/and local councils.

Capacity building support. Civil society organizations have an integral role in preparing women for leadership and policymaking positions which is indispensible to achieve gender mainstreaming goals. Civic education emphasizing capacity building has become imperative to change potential female leaders into active agents of change. There is a pressing need to implement training programs for female public servants, parliament's candidates, local councils' candidates on multidisciplinary concepts and issues in areas of public policy, economics, budgeting, public oversight, governance, democratic values, gender mainstreaming, and human rights.

In addition, developing skills in communication, negotiation, conflict management, decision-making and team building are essential for creating active actors who could contribute to the development of their communities. Furthermore, civic education programs which focus on increasing citizenry political education and awareness of the important role of women in developing modern and knowledgeable societies have become indispensible to promote a culture of gender-equity. In parallel, civil society should play an effective role in contributing to women illiteracy eradication especially in marginalized poor regions.

Moreover, Media is a main pillar in shaping public opinion, yet similar to other institutions, is characterized by a patriarchal culture — where women do not hold decision-making positions—which represents

\footnotetext{
55 UN Women, Op. Cit., p. 2.

56 NCW was established upon the Presidential Decree Number 90 in 2000. Its mandate mainly focus on public policy advocacy to empower women and address their problems to enable them to play their economic, social and political roles (National Council For Women. Retrieved from http://ncwegypt.com/index.php/en/about-ncw/presidential-decree).

57 UNDP Regional Center, UN Policy Directive related to Promoting Women's Electoral and Political Participation through UN Electoral Assistance, December 2013, pp. 19-20 (Arabic Version).

58 Ibid., p. 20.
} 
a menacing threat to the ability of Arab States to disseminate a culture of gender equality ${ }^{59}$. In Egypt, for example, the media ignores women candidates and does not provide them the proper exposure ${ }^{60}$. Civil society should focus on building capacity of media professionals to promote a culture of gender parity as it has become inevitable to have a media where its code of ethics and "self-regulatory bodies acknowledge gender mainstreaming goals" ${ }^{\wedge 1}$. For media to play an effective role in disseminating a culture of gender equality, it has to be restructured and develop a more neutral stand towards gender issues and hence introduce women to the public on an equal footing with men.

Advocacy. Civil society organization plays an important role in advocating women's rights and policies on gender mainstreaming. Intensive advocacy efforts need to take place at different levels. On one hand, civil society organizations must strive to reach out to policy-makers at state and local levels through participating in open hearings, policy papers and policy briefs to present best-buy measures and mechanisms of women empowerment and gender parity. An example was the Constituent Assembly 2013 in Egypt where civil society actively participated in formulating the new constitution. In addition, the civil society has an immense role in disseminating a culture of gender equality through diverse media tools including traditional and new media.

\section{Conclusion}

Women active participation is envisaged as an integral pillar to achieve sustainable socio-economic development in the Arab region. How to create an environment conducive to gender mainstreaming where there is active representation of women in policymaking process sharing same values and interests of the public remains to be a major challenge in the Arab region. Developing such an environment is very much contingent upon having the right support system, where political will, legal framework, and accessibility to financial and technical support aiming at women empowerment and gender mainstreaming are considered to be the main cornerstones. Networking between the government and civil society is indispensible to creating a platform for active participation of women meeting the aspiration of many potential active actors. These two actors should actively interact, coordinating as well as cooperating, to formulate public policies which address gender parity issues and to ensure advancing women political, social and economic status.

\section{References}

Bishu, S. G., \& Jean-Claude, C. Z. (2014). Institutional bureaucratic representation in gender mainstreaming. Global Journal of Interdisciplinary Social Sciences, 3(3), 229-237.

Denhart, R. B., \& Janet, V. D. (2006). Public administration: An action orientation (5th ed.). Belmont, CA: Thomson Wadsworth.

El-Sheikh, S. (2008). Women and local councils in Egypt: An investigative study in light of global trends. Retrieved from http://www.genderclearinghouse.org/upload/Assets/Documents/pdf/almar-walmaraliyat-masr.pdf

Frederickso, H. G., \& Kevin, B. S. (2003). The public administration theory Primer. Colorado, USA: Westview Press.

Hanna, M. M. (2014). Arab-West Report, women in Parliament: Gender justice for Egyptian women?. Retrieved from http://www.arabwestreport.info/year-2014/week-50/03-women-parliament-gender-justice-egyptian-women

Hordosch, S. (2008). Strengthening women's leadership in local government for effective decentralized governance and poverty reduction in Africa: Roles, challenges and strategies. Retrieved from http://unpan1.un.org/intradoc/groups/public/documents/un/unpan031164.pdf

\footnotetext{
59 Katharine Sarikaki, Power, Patriarchy, Profit: Barriers to Gender Mainstreaming in Media Policy, UNESCO, 2014 , p. 66.

${ }^{60}$ Reem Leila, Op. Cit., p. 3.

61 Katharine Sarikaki, Op. Cit., pp. 66-68.
} 
Leila, R. (2015). Promoting women's participation: The National Council for women is discussing ways of supporting women in the upcoming parliamentary elections. Retrieved from http://weekly.ahram.org.eg/News/10031/17/Promoting-women\%E2\%80\%99s-participation.aspx

Mekky, S. (2014). Arab literacy project: Revival of the League of Arab States. Proceedings from 3rd Global Conference on Public Policy and Administration in the Middle East, Lebanon.

Sage Knowledge. (2013). Adult illiteracy worldwide, encyclopedia of social problems: Illiteracy, adult in developing nations. SAGE.

Sarikaki, K. (2014). Power, patriarchy, profit: Barriers to gender mainstreaming in media policy (p. 66). Retrieved from http://www.unesco.org/new/fileadmin/MULTIMEDIA/HQ/CI/CI/pdf/publications/gamag_research_agenda_sarikakis.pdf 